\title{
Green Anionic polymerization of vinyl acetate using Maghnite-Na + (Algerian MMT): Synthesis characterization and reactional mechanism
}

\section{Badia Imene Cherifi}

University Oran1 Ahmed Benbella

Mohammed Belbachir

University Oran1 Ahmed Benbella

Abdelkader Rahmouni ( $\sim$ ramaek23@yahoo.fr)

University Oran1 Ahmed Benbella

\section{Research Article}

Keywords: Polyvinyl acetate, catalyst, Maghnite-Na+, Anionic polymerization, Green chemistry .

Posted Date: April 9th, 2021

DOI: https://doi.org/10.21203/rs.3.rs-390068/v1

License: (c) (i) This work is licensed under a Creative Commons Attribution 4.0 International License.

Read Full License

Version of Record: A version of this preprint was published at Discover Chemical Engineering on November 19th, 2021. See the published version at https://doi.org/10.1007/s43938-021-00005-8. 


\section{Abstract}

In this work, the green polymerization of vinyl acetate is carried out by a new method which consists in the use of clay called Maghnite-Na + as an ecological catalyst, non-toxic, inexpensive and recyclable by simple filtration. X-ray diffraction (XRD) showed that Maghnite-Na + is successfully obtained after cationic treatment (sodium) on raw Maghnite. It is an effective alternative to replace toxic catalysts such as benzoyl peroxide (BPO) and Azobisisobutyronitrile (AIBN) which are mostly used during the synthesis of polyvinyl acetate (PVAc) making the polymerization reaction less problematic for the environment. The synthesis reaction is less energetic by the use of recycled polyurethane as container for the reaction mixture and which is considered as a renewable material and a good thermal insulator which maintains the temperature at $0^{\circ} \mathrm{C}$ for $6 \mathrm{~h}$. The reaction in bulk is also preferred to avoid the use of a solvent and therefore to stay in the context of green chemistry. In these conditions, the structure of obtained polymer is established by Nuclear Magnetic Resonance Spectroscopy 1H NMR and 13C NMR. Infrared spectroscopy (FT-IR) is also used to confirm the structure of PVAc. Thermogravimetric analysis (TGA) showed that it is thermally stable and it starts to degrade from $330^{\circ} \mathrm{C}$ while Differential Scanning calorimetry (DSC) shows that this polymer has a glass transition temperature $\left(\mathrm{Tg}=50^{\circ} \mathrm{C}\right)$. The composition in PVAc/maghnite- $\mathrm{Na}^{+}$(7wt\% of catalyst) is the most tensile resistant with a force of $182 \mathrm{~N}$ and a maximum stress of $73.16 \mathrm{MPa}$, the most flexible $(E=955 \mathrm{MPa})$ and the most ductile $(\varepsilon r=768 \%)$

\section{Introduction}

The chemistry is now moving towards the use of less polluting polymers and synthetic methods that involve low energy and less toxic reagents and therefore environmentally friendly [1-2]. Polyvinyl acetate (PVAc) meets these requirements, it is non-toxic biodegradable under specific conditions and it received considerable attention in various fields such as the pharmaceutical industry as anti-tumor in cosmetics, in the food and food packaging as the cheese coating and gum base for chewing gum [3-4]. This polymer is also used in the building industry as paint and glue for wood, paper and in the textile industry [5-6]. PVAc can be polymerized using various catalysts. Indeed, polymerized vinyl acetate using Benzoyl Peroxide (PBO) as a catalyst at a temperature of $55^{\circ} \mathrm{C}$, while another researchers used Azobisisobutyronitrile (AIBN) in benzene as a solvent at a temperature of $60^{\circ} \mathrm{C}$ [7-8]. Vinyl acetate was also polymerized in emulsion, the reaction was catalyzed by Potassium Persulfate (KPS) in the presence of surfactants at $70^{\circ} \mathrm{C}$ [9-10]. However, these catalysts are not recyclable and require treatment of waste, they are toxic and harmful to human health and can be dangerous if swallowed and cause skin and eye irritation [11-12]. In addition, the synthesis of this polymer in presence of these catalysts is carried out at high temperature requiring more energy which is less attractive economically and environmentally [13-14]. In this perspective, we developed in our laboratory a new method for the synthesis of PVAc with a sustainable way based on the principles of green chemistry [15-16]. For these reasons, we used rigid polyurethane as container for the reaction mixture that we recovered and recycled. Moreover, it is a material that remains undamaged for a very long time and considered today as the insulation that has the best thermal insulation 
maintaining a low temperature $\left(0^{\circ} \mathrm{C}\right)$ for several hours [17]. The advantage of this new method of polymerization is also the use of a catalyst that promotes the synthesis reaction called Maghnite$\mathrm{Na}+$ [18-19]. It is easily available, green, non-toxic, inflammable and inexpensive because it can be separated from the system by simple filtration and reused in other reactions [20-21]. Unlike natural clay minerals maghnite-Na+ has high crystallinity, controllable composition and fewer impurities [22]. For these reasons, the use of such modified maghnite as host materials is expected to be more advantageous than the use of raw natural clay minerals [23]. In the past years, this catalyst has been used successfully as initiator for the anionic polymerization of several acrylamide and vinyl monomers as well as the synthesis of nanocomposites/clay [24-25]. The polymerization of vinyl acetate catalyzed by Maghnite-Na+ is carried out under mild conditions, in bulk without solvent and with the minimum of reagent, reducing the waste treatment [26-27].

\section{Experimental}

\subsection{Material}

The chemicals and reagents used for the synthesis were obtained from commercial sources and were used as received without further purification. Vinyl acetate monomer ( $\geq 99 \%)$ and diethyl ether $(\geq 99 \%)$ were obtained from Sigma Aldrich. $\mathrm{NaCl}$ was purchased from Sigma Aldrich. Raw-Maghnite (Algerian montmorillonite clay) was supplied by BENTAL (Algerian Society of Bentonite). Deionized water was used in the preparation of Maghnite- $\mathrm{Na}^{+}$.

\subsection{Methods}

Nuclear Magnetic Resonance (1H NMR and 13C NMR) spectra were recorded on a BrukerAdvance $300 \mathrm{MHz}$ apparatus in deuterated chloroform (CDCl3). FT-IR (Fourier transform infrared spectroscopy) absorption spectra are recorded on an Alpha Bruker FT-IR spectrometer based on Bruker Optics patented Rock Solid ${ }^{\text {TM }}$ design, flexible sampling and Transmission, Attenuated Total Reflection (ATR), external and diffuse reflection FT-IR sampling accessories.

Thermogravimetric analyzes (TGA) are recorded on a PerkinElmer STA 6000 under nitrogen in the temperature range $30-690^{\circ} \mathrm{C}$ with a speed of $20^{\circ} \mathrm{C} / \mathrm{min}$. X-Ray Diffraction (XRD) studies of the clay are done using Bruker AXS D8 diffractometer with the VÅNTEC-500 detector using Cu-Ka radiation $(\lambda=$ $1.5418 \AA$ A). Differential Scanning Calorimetry (DSC) measurements are carried out on a TA instrument Q500, the heating rate is $10^{\circ} \mathrm{C} / \mathrm{min}$ from $-20^{\circ} \mathrm{C}$ to $200^{\circ} \mathrm{C}$ under $\mathrm{N}_{2}$ and the sample weighed about $20 \mathrm{mg}$. Tensile tests were conducted using a LLoyd LR/10KN Universal Machine at room temperature and crosshead speed of $50 \mathrm{~mm} \mathrm{~min}^{-1}$ for the determination of tensile modulus and yield strength, according to the standard ASTM D638.

\subsection{Preparation of Maghnite-Na+}


In an Erlenmeyer of $1 \mathrm{~L}, 15 \mathrm{~g}$ of raw Maghnite is put in $400 \mathrm{ml}$ of distilled water and the mixture was stirred at room temperature for $(2 \mathrm{~h})$. Then $600 \mathrm{ml}$ of a sodium chloride solution $(1 \mathrm{M})$ is added to the preceding mixture and left stirring for $(48 \mathrm{~h})$ at room temperature. After this time, the product is filtered and washed with distilled water until complete removal of the $\mathrm{Cl}$-ions. This is confirmed by the silver nitrate test. The last step is to crush the obtained Maghnite-Na+ after drying in the oven at $105^{\circ} \mathrm{C}$ .Structure of maghnite is established by FT-IR and XRD.

\subsection{Synthesis of Poly (vinyl acetate )}

The polymerization of vinyl acetate was carried out in bulk and in two steps: the first step is the activation of the monomer by the catalyst. Amount of vinyl acetate $(1 \mathrm{~g}, 0.012 \mathrm{~mol})$ is mixed with Maghnite-Na+ (catalyst) at various weight percentages $(1 \%, 2 \%, 3 \%, 5 \%$ and $7 \%$ ) in a sealed tube for one hour at a temperature of $0^{\circ} \mathrm{C}$. The low temperature is maintained using a container which does not require energy to cool; it is made from polyurethane waste (it is a thermal insulator) which allowed the reaction to proceed smoothly under mild conditions that respect the principles of green chemistry. Then, in the second step, the remaining amount of the monomer $(4 \mathrm{~g}, 0.046 \mathrm{~mol})$ is added to the previous mixture and the polymerization is conducted at various times, still at $0^{\circ} \mathrm{C}$. At the end of the reaction, solid Maghnite-Na+ is removed from the mixture by filtration then the polymer is obtained by precipitation of the filtrate in methanol as show in (Scheme1). The polymerization of vinyl acetate has been done by using different (solvents). In our work we will achieve a heterogeneous polymerization based on the principles of green chemistry, it is assumed that it proceeds according to an anionic mechanism.

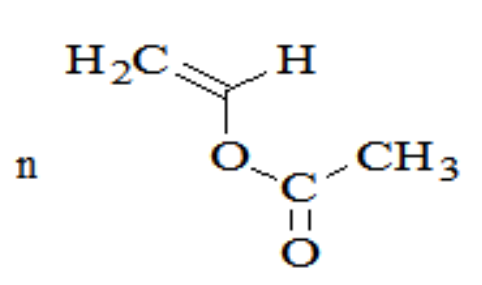

Vinyl acetate

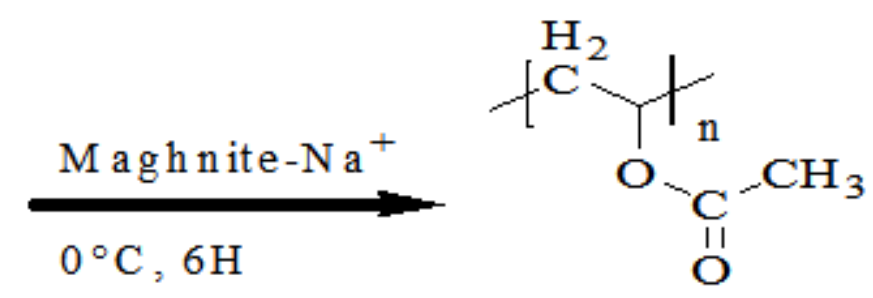

Poly (vinyl acetate)

Scheme 1. Schematic representation of the synthesized polymer (PVAc) catalyzed by maghnite-Na+ under optimal condition $\left(0^{\circ} \mathrm{C}, 6\right.$ hours $)$.

\section{Results And Discussion}

In this work, we have prepared for the first time the PVAc by an anionic polymerization from VAc under effect of heterogeneous catalyst called maghnite-Na+ (Algerian MMT). The structure, morphology, mechanical and physical chemical properties of the synthesized PVAc was found to vary depending on the different amount of catalyst, the temperature and time. (Scheme2) show experimental equipment of the anionic polymerization of PVAc catalyzed by heterogeneous catalyst called maghnite- $\mathrm{Na}^{+}$(Algerian MMT). 


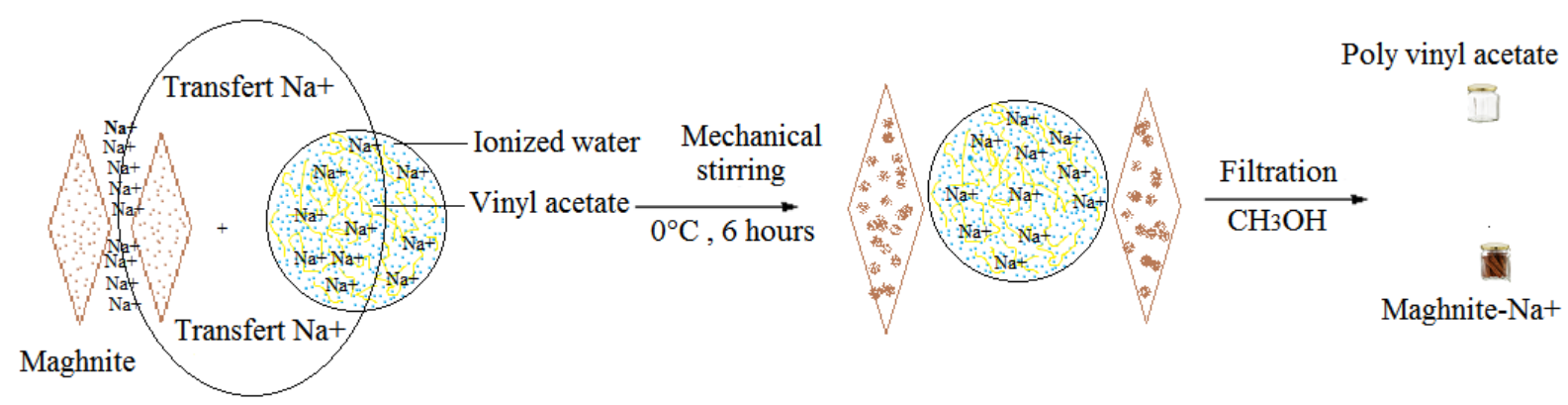

Scheme 2. Experimental equipment for synthesis of anionic poly (vinyl acetate) catalyzed by maghnite$\mathrm{Na}+$

\subsection{Catalyst characterization}

Maghnite- $\mathrm{Na}^{+}$is analyzed by FT-IR spectroscopy which confirmed the structure of montmorillonite. A broad band between $3200 \mathrm{~cm}-1$ and $3500 \mathrm{~cm}-1$ characteristic of the $\mathrm{OH}$ group bonded to octahedral aluminum is observed in (Figure 1). The band at $1629 \mathrm{~cm}-1$ corresponds to the stretching vibration of $\mathrm{H}_{2} \mathrm{O}$. The FT-IR spectrum also shows the presence of an intense band at $984 \mathrm{~cm}-1$ attributed to the Si-O-Si stretching vibration in the tetrahedral layer. The characteristic bands of Si-OAl and Si-O-Mg groups appear respectively at $516.46 \mathrm{~cm}-1$ and $439.20 \mathrm{~cm}-1$ [28].

The X-ray powder diffraction profiles (Figure 2) show that there is an increase in basal spacing (d001) from $9.08 \AA$ in the raw-maghnite after $12.70 \AA$ this increase in the interlayer distance is explained by the adsorption of a water molecule on the surface of the sheets of the montmorillonite reflecting the changes in interlayer cation as a result of the basic treatment [29]. The other weak peaks are related to the structure of aluminum-oxygen octahedron and silicon- oxygen tetrahedron in the montmorillonite [30].

\subsection{Polymer characterization}

The polymerization of PVAc is also established by the Infrared spectroscopy (FT-IR). Indeed, the characteristic bands of the vinyl group at $1646 \mathrm{~cm}-1$, stretching band at $949 \mathrm{~cm}^{-1}$ at $873 \mathrm{~cm}^{-1}$ corresponding to $C=C$ and the stretching vibration at $1132.99 \mathrm{~cm}^{-1}$ corresponding to the group $=C-0-C$ observed in FT-IR spectrum of vinyl acetate (Figure 3) that disappear in FT- IR spectrum of PVAc (Figure 4) confirming that polymerization of the monomer catalyzed by Maghnite-Na ${ }^{+}(7 \% \mathrm{wt})$ has been successfully completed [31]. In addition, the stretching vibration $\mathrm{C}=0$ and the band corresponding to the ester group of vinyl acetate which appear, respectively at $1728.97 \mathrm{~cm}^{-1}$ and at 1206.74 $\mathrm{cm}^{-1}$ shift to $1755.89 \mathrm{~cm}^{-1}$ and $1224.83 \mathrm{~cm}^{-1}$ for PVAc [32]. The stretching vibrations of $\mathrm{CH}(2923.82$ $\left.\mathrm{cm}^{-1}\right), \mathrm{CH}_{2}\left(2923.82 \mathrm{~cm}^{-1}\right), \mathrm{CH}_{3}\left(3017.66 \mathrm{~cm}^{-1}\right)$ and $\mathrm{COCH}_{3}\left(1018.77 \mathrm{~cm}^{-1}\right)$ are observed in the spectra of PVAC [33].

The structure of PVAc is analyzed and confirmed by $1 \mathrm{H}$ NMR and ${ }^{13} \mathrm{C}$ NMR spectroscopy. The peaks at 21.04 ppm, 39.16 ppm, 66.98 ppm and 170.38 ppm observed in the 13C NMR spectrum of (Figure 6) are 
assigned, respectively, to the groups $\mathrm{CH} 3, \mathrm{CH} 2, \mathrm{CH}$ and $\mathrm{C}=0$ of the polymer [34]. The $1 \mathrm{H}$ NMR spectrum (Figure 5) also confirms the PVAc structure by the presence of two peaks centered at 1.52 and 1.78 ppm corresponding to the methylene group $\left(\mathrm{CH}_{2}\right)$ corroborated by the disappearance of the peaks (two doublets) at $4.56 \mathrm{ppm}$ and at $4.87 \mathrm{ppm}$ corresponding to the double bond $\mathrm{H}_{2} \mathrm{C}=\mathrm{CH}_{2}$ [35]. The peak situated at 2.01-2.05 ppm is assigned to the methyl group $\left(\mathrm{CH}_{3}\right)$ and the broad peak located at 4.88 ppm for the $\mathrm{CH}_{2}$ group. These results are similar to the literature [36].

\subsection{Thermal properties of polymer}

The Thermogravimetric analysis is used in order to study the thermal stability of PVAc. The obtained thermogravimetric curve which is the representation of the relative weight loss depending on the heating temperature is given in (Figure 7 ) and which shows that there are two distinct weight loss stages. The first and intense weight loss between 300 and $400^{\circ} \mathrm{C}(69 \% \mathrm{wt})$ corresponds to the deacetylation step which consists in smaller fragments corresponding to the acetic acid mother molecule [37]. During the deacetylation process, $(\mathrm{CH}) \mathrm{n}$ fragments evaporate from the polymeric material indicating scission of the polymer main chain at the end [38]. At the temperature of $400^{\circ} \mathrm{C}$, PVAc decomposes into a highly regular unsaturated material or polyene [39]. The second weight loss observed at high temperatures, in the range of 400 to $500^{\circ} \mathrm{C}(19 \% \mathrm{wt})$ can be attributed to the complete degradation of the formed polyene through chain scission reactions. These results are in agreement with literature [40]

Analysis by Differential scanning calorimetry (DSC) determines the thermal properties of PVAc and in particular its glass transition temperature, $\mathrm{Tg}$, which corresponds to the passage of the polymer from the vitreous state to the rubbery state [41]. The hermetic capsule containing a mass of the polymer is introduced into the oven at room temperature and then the temperature is lowered to $-20^{\circ} \mathrm{C}$ by a flow of $\left(\mathrm{N}_{2}\right.$ gas). After that, a temperature gradient of $-20^{\circ} \mathrm{C}$ to $200^{\circ} \mathrm{C}$ is achieved with a rate of $10^{\circ} \mathrm{C} / \mathrm{min}$ [42]. At $200^{\circ} \mathrm{C}$, the temperature is again lowered to $-20^{\circ} \mathrm{C}$, again with $10^{\circ} \mathrm{C} / \mathrm{min}$ through the $\mathrm{N}_{2}$ gas flows, before a second temperature rise in the same conditions. The DSC thermogram thus obtained allows the determination of $\mathrm{Tg}$. The first passage in temperature gives an enthalpy relaxation peak which depends on the internal tensions, resulting from the synthesis process and the thermal history of the polymer cannot be taken into consideration [43]. To eliminate the «thermal history» of PVAc, Tg is determined from the second pass. The obtained curve (Figure 8) shows that $\mathrm{Tg}$ is about $50^{\circ} \mathrm{C}$ which is in agreement with the data from the literature [44].

\subsection{Mechanical properties of polymer}

In general, mechanical properties of materials are strongly influenced by the microstructure. The mechanical properties of the native PVAc were characterized by tensile testing. To evaluate the effect of Maghnite-Na ${ }^{+}$catalyst (Algerian MMT) in PVAc, we prepared five samples with the same procedure and in different ratios of VAc/Maghnite-Na ${ }^{+}$(99:1, 98:2, 97:3, 95:5, 93:7). The young's modulus and yield strength are greatly enhanced as show in (Table1). It shows that the mecanicals properties depend on amount of catalyst. 
Table 1. Mechanical properties of PVAc /Maghnite- $\mathrm{Na}^{+}$samples

\begin{tabular}{|c|c|c|c|c|}
\hline Sample & $\begin{array}{c}\text { Catalyst (w } \\
\%)\end{array}$ & $\begin{array}{c}\text { Young's modulus } \\
\text { (MPa) }\end{array}$ & $\begin{array}{c}\text { Elongation } \\
\text { at break (\%) }\end{array}$ & Yield strength (MPa) \\
\hline $\begin{array}{c}\text { Maghnite- } \\
\text { Na+ }\end{array}$ & - & 845 & 69.45 & - \\
\hline PVAc (pure) & - & 312 & 45.82 & - \\
\hline PVAc-1/Mag & 1 & 1094 & 70.02 & 41.09 \\
\hline PVAc -2/Mag & 2 & 1126 & 72.54 & 55.13 \\
\hline PVAc -3/Mag & 3 & 1199 & 73.95 & 60.22 \\
\hline PVAc -4/Mag & 5 & 1213 & 75.36 & 70.23 \\
\hline PVAc -5Mag & 7 & 1289 & 86.65 & 82.17 \\
\hline
\end{tabular}

The tensile test was carried out to evaluate the tensile properties of the various samples compositions in order to determine the influence of the addition of the clay on the tensile properties of the virgin matrix. Young modulus, tensile strength and elongation at break were evaluated as a function of the mass fraction of clay in all series of samples. Thus Young's modulus increased in compositions with the highest clay contents, (1-7\%). The composition in PVAc/maghnite-Na ${ }^{+}(7 \mathrm{w} \%$ of catalyst) has the highest tensile values [45]. A Significant increase in the elongation at the break to PVAc/maghnite- $\mathrm{Na}^{+}$was observed. This was attributed to the aggregate formation of maghnite-Na+ within the polymer matrix and the matrix with $7 \mathrm{wt} \%$ maghnite-Na ${ }^{+}$exhibited an maxima elongation at break of $86.65 \%$.These dramatic improvements were attributed to the fine dispersion of maghnite-Na+ in the polymer matrix [46].This is attributed to the interactions between the polymer chains and the nanometric layers of the clay with a decrease in the value of the young's modulus [47]. This composition is the most tensile resistant with a force of $182 \mathrm{~N}$ and a maximum stress of $73.16 \mathrm{MPa}$, the most flexible ( $\mathrm{E}=955 \mathrm{MPa})$ and the most ductile ( $(\varepsilon r=768 \%)$. From these results, it can be deduced that the incorporation of the clay into the PVAc matrix, with different percentages, has significantly improved all of its tensile properties [48].

\subsection{Morphological properties of polymer}

Scanning electron microscopy SEM was used to see the distribution of the maghnite clay in the polymer synthesized [49]. The morphology of the surfaces was observed in (Fig 9A, B, C and D) and the representative scanning electron micrographs of raw maghnite, maghnite- $\mathrm{Na}^{+}$and $\mathrm{PVAc} / \mathrm{Maghnite}-\mathrm{Na}+$ from the anionic polymerization, respectively. The particle diameter of raw maghnite (Fig 9A) and maghnite-Na+ (Fig 9B) ranged from 50 to $100 \mathrm{~nm}$, while PVAc/Maghnite-Na+(Fig 9C) and pure PVAc (Fig 9D) ranged from 150 to $200 \mathrm{~nm}$, the smaller MMT particles were adsorbed around the larger PVAc particles to form the tube structure [50]. SEM images of PVAc/MMT (Fig. 9C) and pure PVAc (Fig 9D) showed that when the maghnite was incorporated in the PVAc, the average particles size of the composite was increased to $200 \mathrm{~nm}$. The obtained results indicate that the polymerizing chains were aggregated into the clay interlayer regions and consequently the exfoliation of maghnite- $\mathrm{Na}^{+}\left(\mathrm{MMT}^{\mathrm{N}} \mathrm{Na}^{+}\right)$ was almost completed [51]. 


\section{Kinetic'S Studies}

The effect of the amount of maghnite on the yield of polymerization expressed by using various weight ratios Mag-Na+/monomer, on the polymerization yield of vinyl acetate is showed in (Figure10). The polymerization is carried out in bulk at $0^{\circ} \mathrm{C}$ for $(6 \mathrm{~h})$ using various amounts of Mag-Na+ $(3 \%, 4 \%, 6 \%$, $7 \%, 10 \%$ and $12 \% \mathrm{wt} / \mathrm{wt}$ ). It can be noted that the yield of PVAc increases with increasing the amount of the catalyst in which the effect of Mag- $\mathrm{Na}^{+}$as a catalyst is clearly shown [52]. However, the maximum yield is obtained at $7 \%$ by weight of $\mathrm{Mag}^{-\mathrm{Na}^{+}}$and from this rate it remains unchanged [53]. The phenomenon (increasing of the yield) can be attributed to the active sites available in the catalyst which are responsible for the initiation and acceleration of the polymerization reaction until the saturation of these sites (stabilization of the yield) [54].

(Figure 11) shows the effect of time on the yield of PVAc. The polymerization of vinyl acetate is carried out at different times in bulk at $0^{\circ} \mathrm{C}$ using $(7 \%)$ by weight of Maghnite-Na+. The obtained results show that the yield increases slightly during four hours of reaction and this can be considered as an induction period [55]. From that time, the yield begins to increase rapidly until it stabilizes and reaching a maximum value of $72.85 \%$ after 6 hours of reaction [56].

\section{Proposed Mechanism}

This new anionic polymerization consists of three main reactions: (a) initiation, (b) propagation, and (c) termination, as described in (Scheme 3). However, the initiation reaction is generally fast and is not reflected in the overall rate of the polymerization [57]. The interaction of propagating ion pairs with functional groups of the monomer or the polymer chain can affect the propagation rate and in some cases induces side reactions that can cease the polymerization [58]. The termination is brought about intentionally using a suitable electrophile, which can be useful for end group modification [59]. 


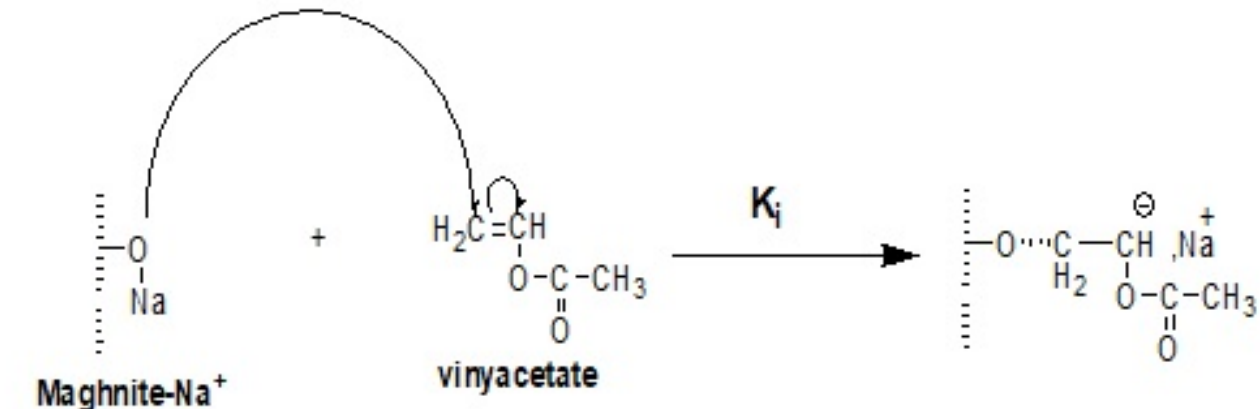

\section{Propagation}

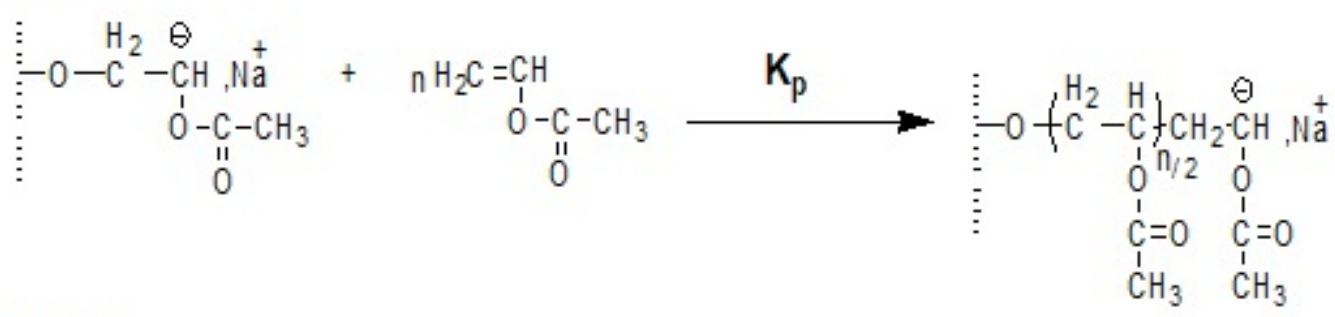

terminaison
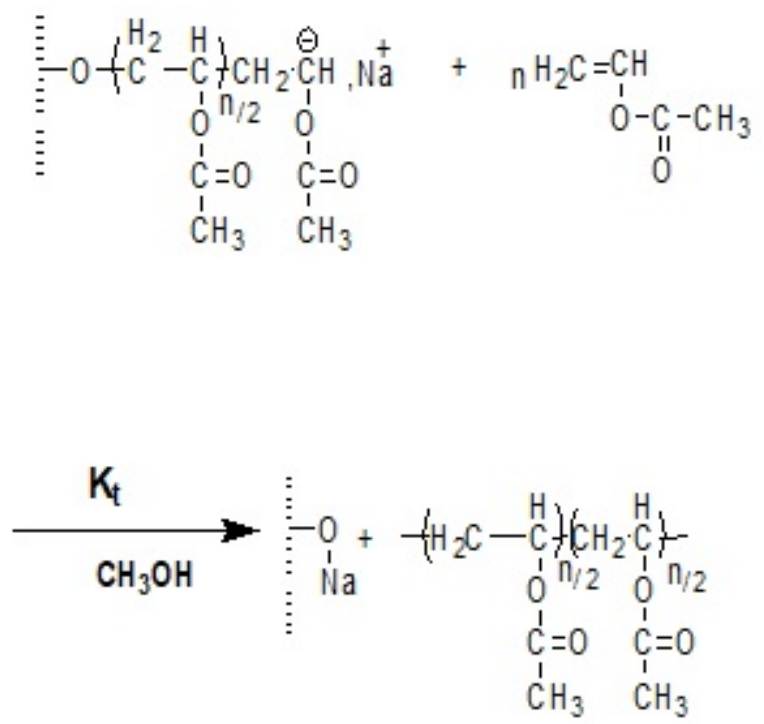

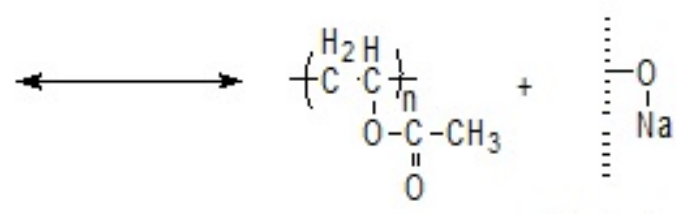

polyacétate de vinyle Maghnite- $\mathrm{Na}^{+}$

Scheme 3. Proposed mechanism of poly vinyl acetate (PVAc) catalyzed by maghnite-Na ${ }^{+}$(Algerian MMT)

\section{Conclusion}

In this work, poly (vinyl acetate) is synthesized and structurally characterized. The synthesis of this polymer is carried out successfully by highlighting a completely ecological process by integrating the principles of green chemistry. This new approach allows developing an energy-efficient process by using a recycled polyurethane-based as container for the reaction mixture which is an excellent thermal insulator and thus let it possible to work at low temperature for a long time. In addition, PVAc is synthesized for the first time in bulk using an efficient green catalyst called Maghnite-Na+ ${ }^{+}$under 
heterogeneous conditions. The polymerization proceeds via an anionic mechanism due to the presence of intercalated sodium ion ( $\mathrm{Na}+)$ in the lamellar structure of the montmorillonite. FT-IR spectroscopy as well as 1H NMR and 13C NMR spectroscopy confirm the structure of PVAc. TGA shows that the obtained polymer is thermally stable with a degradation temperature higher than $300^{\circ} \mathrm{C}$ and its glass transition temperature is $50^{\circ} \mathrm{C}$ which is obtained by DSC analysis. Consequently, Maghnite-Na+ showed that it is an attractive eco-catalyst with many advantages such as being cheap, safe and reusable. Indeed, it can be easily separated from the polymer products and regenerated by heating to a temperature above $100^{\circ} \mathrm{C}$.

\section{Declarations}

\section{Acknowledgment}

All our gratitude to the anonymous referees for their careful reading of the manuscript and valuable comments which helped in shaping this paper to the present form. We thank all laboratory staff of polymer chemistry from the university of Oran 1 Ahmed Benbella (Algeria) for their kind cooperation and help ( Professor Mohammed Belbachir and doctor Abdelkader Rahmouni). This work was supported by the DGRSDT of Algeria, and was carried out within the State Program of second national forum.

\section{Conflict of interest statement}

The authors declare that they have no known competing financial interests or personal relationships that could have appeared to influence the work reported in this paper.

\section{References}

[1]. Duan B, Yuan X, Zhu Y, Zhang Y, Li X, Zhang Y et al (2006) A nanofibrous composite membrane of PLGA-chitosan/PVA prepared by electrospinning. Eur Polym J 42:2013-2022 [2]. Asaad JN, Mansour SH, Abd-El-Messieh SL (2013) Some studies on poly(ethylene-co-vinyl acetate), acrylonitrile butadiene copolymer, and their blend reinforced with carbon black. J Reinf Plast Comp 32:1-12

[3]. Joseph A, Mathai AE, Thomas S (2003) Sorption and diffusion of methyl substituted benzenes through cross-linked nitrile rubber/poly(ethylene co-vinyl acetate) blend membranes. J Membr Sci 220:13-30

[4]. Karakus G, Akin Polat Z, Yenidunya AF, Zengin HB, Karakus CB (2013) Synthesis, characterization and cytotoxicity of novel modified poly[(maleic anhydride)-co-(vinyl acetate)]/noradrenaline conjugate. Polym Int 62:492-500

[5].Cho J, Paul D (2001) Nylon 6 nanocomposites by melt compounding. Polymer 42:1083-1094.[1]. Hyun Y, Lim S, Choi H, John M (2001) Rheology of poly(ethylene oxide)/organoclay nanocomposites. Macromolecules 34:8084-8093 
[6]. Chung J, Oh KS, Kwak S-Y (2007) Evaluation of the degree of exfoliation in poly( $\varepsilon$ caprolactone)/organoclay nanocomposites based on viscoelastic relaxation. Macromol Mater Eng 292:627-633

[7]. Yang D-Y, Liu Q-X, Xie X-L, Zeng F-D (2006) Structure and thermal properties of exfoliated PVC/layered silicate nanocomposites via in situ polymerization. J Therm Anal Calorim 84:355-359

[8]. Lozinsky VI, Vainerman ES, Domotenko LV, Mamtsis AM, Titova EF, et al. (1986) Study of cryostructurization of polymer systems VII. Structure formation under freezing of poly (vinyl alcohol) aqueous solutions. Colloid and Polymer Science 264: 19-24.

[9]. Kenawy E-R, Bowlin GL, Mansfield K, Layman J, Simpson DG, Sanders EH et al (2002) Release of tetracycline hydrochloride from electrospun poly(ethylene-co-vinyl acetate), poly (lactic acid), and a blend. J Control Rel 81:57-64

[10]. Kitotsukuri T, Masuda T, Tsutsumi N, Sakai W, Nagata M (1995) Poly(ethylene terephthalate copolymer)s with smaller amounts of poly(ethylene glycol)s and poly(butylene glycol)s. Polymer $36: 2629-2635$.

[11]. Nijenhuis AJ, Colstee E, Grijpma DW, Pennings AJ (1996) High molecular weight poly(L-lactide) and poly(ethylene oxide) blends: thermal characterization and physical properties. Polymer 37:5849-5857

[12]. Alexandre M, Beyer G, Henrist C, Cloots R, Rulmont A, Jerome R, Dubois P (2001) “Onepot"preparation of polymer/clay nanocomposites starting from $\mathrm{Na}$ - montmorillonite. 1. Melt intercalation of ethylene-vinyl acetate copolymer. Chem Mater 13:3830-3832

[13]. Yang, X., Li, L., Shang, S., and Tao, X. M. (2010). Synthesis and Characterization of Layer-Aligned Poly(vinyl Alcohol)/graphene Nanocomposites. Polymer. 51(15): 3431 - 3435

[14]. Ma P, Hristova-Bogaerds DG, Goossens JGP, Spoelstra AB, Zhang Y, Lemstra PJ (2012) Toughening of poly(lactic acid) by ethylene-co-vinyl acetate copolymer with different vinyl acetate contents. Eur Polym J 48:146-154

[15]. Lee CH, Kim HB, Lim ST, Choi HJ, Jhon MS (2005) Biodegradable aliphatic polyester-poly (epichlorohydrin) blend/organoclay nanocomposites; synthesis and rheological characterization. J Mater Sci 40:3981-3985

[16]. M. Belbachir, A.Bensaoula. Composition and method for catalysis using bentonite. U.S. Patent.B2 2006. 7,094,823.

[17]. Volfova P, Chrastova V, Cernakova L, Mrenica J, Kozankova J (2001) Properties of polystyrene/poly(butyl acrylate) core/shell polymers modified with $\mathrm{N}$-methylol acrylamide. Macromol Symp 170:283-290 
[18] Rahmouni A., Belbachir M., Ayat M., Structural Inverstigation : Anionic Polymerisation of Acrylamide under Micowave Irradiation using Maghnite-Na ${ }^{+}$Clay (Algerian MMT) as Initiator, Bull. Chem. Raction. Engineering. Catalysis, 13 (2): 262-274 (2018).

[19] Ayat M., Belbachir M., Rahmouni A., Synthesis of Block Copolymers Consists on Vinylidene Chloride and a- Methylstyrene by Cationic Polymerization using an Acid Exchanged Motmorillonite Clay as Heterogeneous Catalyst (Algerian MMT), J. Molecular Structure, 1139:381-389(2017).

[20] Ayat M., Belbachir M., Rahmouni A., Selective Synthesis, Characterization, and Kinetics Studies of poly (a-Methyl styrene) induced by Maghnite-Na+ Clay (Algerian MMT), Bull. Chem. Reaction Engineering. Catalysis, 11 (3): 376-388(2016).

[21] Qiao Z, Xie Y, Chen M, Xu J, Zhu Y, Qian Y (2000) Synthesis of lead sulfide/(polyvinyl acetate) nanocomposites with controllable morphology. Chem Phys Lett 321:504-507

[22] Varghese H, Johnson T, Bhagawan SS, Joseph S, Thomas S, Groeninckx G (2002) Dynamic mechanical behavior of acrylonitrile butadiene rubber/poly(ethylene-co-vinyl acetate) blends. J Polym Sci Polym Phys Ed 40:1556-1570

[23]. Rahmouni., A. Harrane., A. and Belbachir., M.(2012). Thermally stable forms of pure polyaniline catalyzed by an acid-exchanged MMT clay called maghnite- $\mathrm{H}+$ as an effective catalyst. International journal of polymer science.

[24]. Belbachir., M., and Bensaoula., A. (2001).Composition and method for catalysis using bentonites," United States Patent Number: 6274527 B1.

[25]. Sarac A, Yildirim H (2003) Effect of initiators and ethoxylation degree of non-ionic emulsifiers on vinyl acetate and butyl acrylate emulsion copolymerization in the loop reactor. J Appl Polym Sci 90:537543

[26]. Kherroub, D.E., Belbachir, M., Lamouri, S. (2015). Nylon 6/clay Nanocomposites Prepared with Algerian Modified Clay (12-maghnite). Research on Chemical Intermediates, 41: 5217-5228.

[27]. Yao M, Deng H, Mai F, Wang K, Zhang Q, Chen F (2011) Modification of poly(lactic acid)/poly(propylene carbonate) blends through melt compounding with maleic anhydride. EXPRESS Polym Lett 5:937-949

[28]. Nemtoi G, Beldie C, Tircolea C, Popa I, Cretescu I, Humelnicu I, Humelnicu D (2001) Behaviour of the poly(maleic anhydride-co-vinyl acetate) copolymer in aqueous solutions. Eur Polym J 37:729-735

[29]. Opaprakasit M, Petchsuk A, Opapraksit P, Chongprakobkit S (2009) Effect of synthesis conditions on chemical structures and physical properties of copolyesters from lactic acid, ethylene glycol and dimethyl terephthalate. eXPRESS Polym Lett 3:458-468. 
[30]. Grzebieniak K, Ratajska M, Strobin G (2001) Estimation of hydrolysis and biodegradation processes in ethylene terephthalate and lactic acid copolymers. Fibres Text East Eur 9:61-65

[31]. Abd El-Ghaffar MA, Youssef AM, Abd El-Hakin AA (2015) Polyaniline nanocomposites via in situ emulsion polymerization based on montmorillonite: preparation and characterization. Arab J Chem 8:771-779

[32]. Jung, H.M.; Lee, E.M.; Ji, B.C.; Deng, Y.; Yun, J.D.; Yeum, J.H. Poly(vinyl acetate)/poly(vinyl alcohol)/montmorillonite nanocomposite microspheres prepared by suspension polymerization and saponification.Colloid Polym. Sci. 2007, 285, 705-710.

[33]. Corobea MC, Uricanu VI, Donescu D, Radovici C, Serban S, Garea S, lovu H (2007) Poly(vinyl acetate)clay hybrids prepared via emulsion polymerization, assisted by a nonionic surfactant. Mater Chem Phys 103:118-126

[34]. Lira-Cantu' M, Go'mez-Romero P (1998) Electrochemical and chemical syntheses of the hybrid organic-inorganic electroactive material formed by phosphomolybdate and polyaniline. Application as cation-insertion electrodes. Chem Mater 10:698-702.

[35]. Mohsen-Nila M, Doulabi FSM (2011) Synthesis and characterization of polyvinyl acetate/montmorillonite nanocomposite by in situ emulsion polymerization technique. Polym Bull $66: 1255-1265$

[36]. Ko M, Jho J, Jo W, Lee M (2002) Effect of matrix viscosity on clay dispersion in preparation of polymer/organoclay nanocomposites. Fiber Polym 3:103-108.

[37]. Choudalakis, G. \& Gotsis, A.D. (2009). Permeability of polymer/clay nanocomposites: A review. European polymer Journal, 45, 967-984 .

[38]. Sahu M, Samal R, Biswal T, Sahoo PK (2014) Synthesis and characterization of poly(vinyl acetate)/MMT nanocomposite flame retardant. Int J Mater Sci 4:91-98

[39]. Carra S, Sliepcevich A, Canevarolo A, Carra S (2005) Grafting and adsorption of poly(vinyl) alcohol in vinyl acetate emulsion polymerization. Polymer 46:1379-1384

[40]. Chen LJ, Qin YS, Wang XH, Li YS, Zhao XJ, Wang FS (2011) Toughening of poly(propylene carbonate) by hyperbranched poly(ester-amide) via hydrogen bonding interaction. Polym Int 60:16971704

[41]. Yuki H, Hatada K, Ota K, Kinoshita I, Murahashi S, et al. (1969) Stereospecific polymerization of benzyl vinyl ether by BF3 .OEt2 . Journal of Polymer Science Part A-1: Polymer Chemistry 7: 1517-1536.

[42]. Cui L, Ma X, Paul DR (2007) Morphology and properties of nanocomposites formed from ethylenevinyl acetate copolymers and organoclays. Polymer 48:6325-6339 
[43]. Qiao Z, Xie Y, Chen M, Xu J, Zhu Y, Qian Y. Synthesis of lead sulfide/(polyvinyl acetate) nanocomposites with controllable morphology. Chem Phys Lett 2000; 321: 504-7.

[44]. Gajria AM, Davé V, Gross RA, McCarthy SP (1996) Miscibility and biodegradability of blends of poly(lactic acid) and poly(vinyl acetate). Polymer 37:437-444

[45]. Bruch M, Mäder D, Bauers F, Loontjens T, Mülhaupt R. Melt modification of poly(styrene-co-maleic anhydride) with alcohols in the presence of 1,3-oxazolines. J Polym Sci 2000; 38:1222-31.

[46]. Wang XY, Peng SW, Dong LS (2005) Effect of poly(vinyl acetate) (PVAc) on thermal behavior and mechanical properties of poly(3-hydroxybutyrate)/poly(propylene carbonate) (PHB/PPC) blends. Colloid Polym Sci 284:167-174

[47]. Zhang ZH, Lee JH, Lee SH, Heo SB, Pittman CU (2008) Morphology, thermal stability and rheology of poly(propylene carbonate)/organoclay nanocomposites with different pillaring agents. Polymer 49:2947-2956

[48]. Garnaik, B. and Thombre, S. M., "Self-association through hydrogen bonding and sequence distribution in poly (vinyl acetate-co-vinyl alcohol) copolymers”, J. Appl. Polym. Sci., 72(1), 123 (1999).

[49]. Lai MF, Li J, Liu JJ (2005) Thermal and dynamic mechanical properties of poly(propylene carbonate). J Therm Anal Calorim 82:293-298

[50]. Navarchian, A. H. and Mousazadeh, S., "The effects of reaction variables on solution polymerization of vinyl acetate and molecular weight of polyvinyl alcohol using Taguchi experimental design", Iran. J. Polym. Sci. Technol., 22, 341 (2009).

[51]. Zhang J, Wilkie CA (2004) A carbocation substituted clay and its styrene nanocomposite. Polym Deg Stab 83:301-307

[52]. Gardner DL, McNeill IC (1969) Investigations of thermal elimination reactions of polymers by thermal volatilization analysis and ultraviolet spectroscopy. J Therm Anal 1(4):389-402

[53]. Shirahase T, Komatsu Y, Marubayashi H, Tominaga Y, Asai S, Sumita M (2007) Miscibility and hydrolytic degradation in alkaline solution of poly(L-lactide) and poly( $p$-vinyl phenol) blends. Polym Degrad Stab 92:1626-1631

[54]. Fecchio BD, Valandro SR, Neumann MG, Cavalheiro CCS (2016) Thermal decomposition of polymer/montmorillonite nanocomposites synthesized in situ on a clay surface. J Braz Chem Soc 27:278-284

[55]. Razavi-Nouri M, Karami M (2014) Effect of rubber content on morphology and thermal and rheological behaviors of acrylonitrile-butadiene rubber/poly(ethylene-co-vinyl acetate)/organoclay nanocomposites. Polymer 55:6940-6947. 
[56]. Klemm, E.; Schulze, T., Ring-opening polymerization of heterocycles bearing substituted and unsubstituted exo-methylene groups. A review. Acta Polym. 1999,50, (1), 1-19.

[57]. Razavi-Nouri M, Karami M (2018) Water sorption kinetics of acrylonitrile-butadiene rubber/poly (ethylene-co-vinyl acetate)/organoclay nanocomposites. Polymer 154:101-110

[58]. J. Gue, K. Y. Choi, and F. J. Schork, "Miniemulsion copoly-merization of ethylene and vinyl acetate", Macromol. React.Eng., 3, 412 (2009).

[59]. Z. Wenwei, Z. Xiaoguang, Y. Li, Z. Yuefang, and S. Jiazhen,“Determination of the vinyl acetate content in ethylene-vinylacetate copolymers by thermogravimetric analysis", Polymer,35, 3348 (1994).

Figures

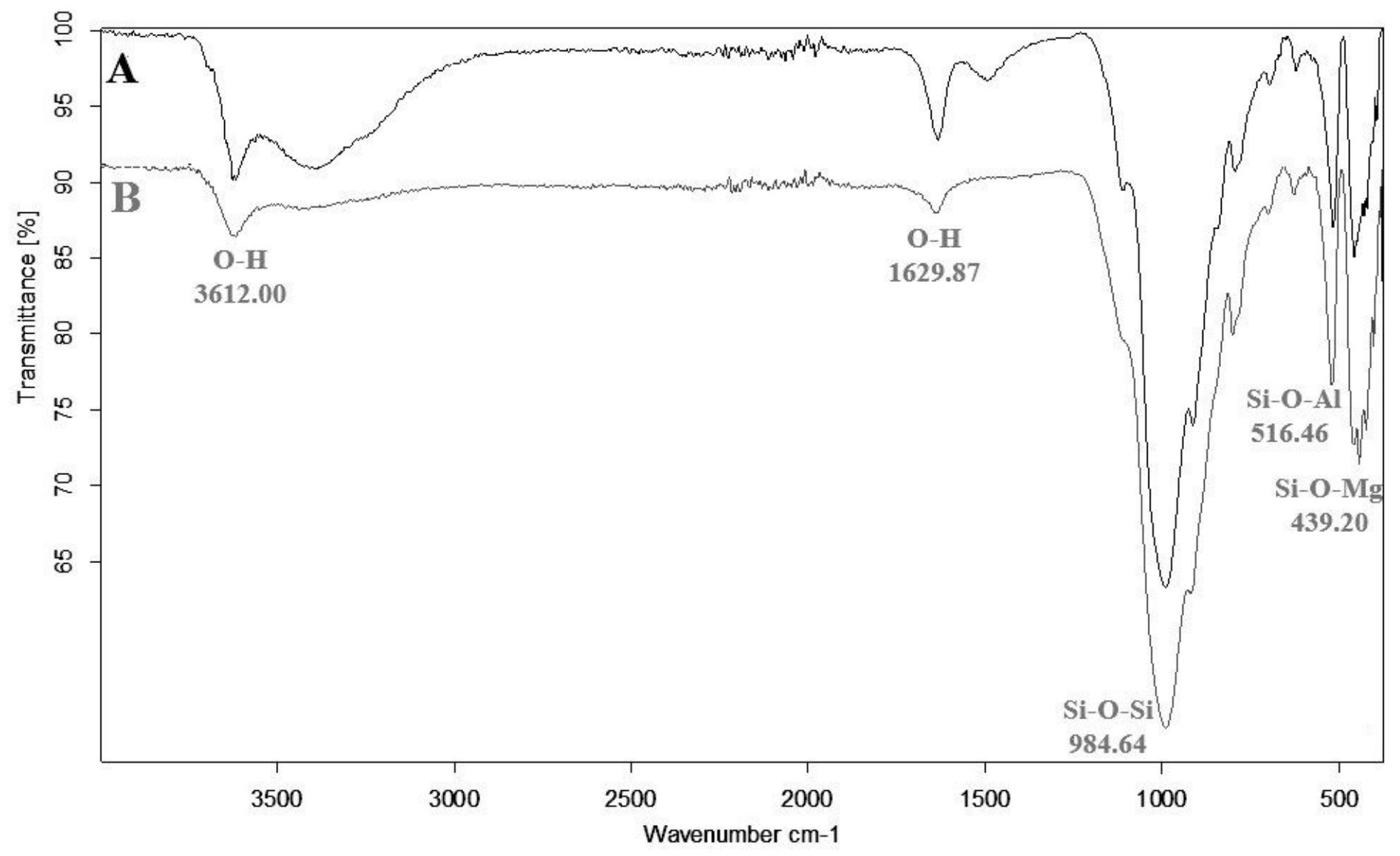

Figure 1

FT-IR spectra of (A) Raw-Maghnite and (B) Maghnite-Na+ 


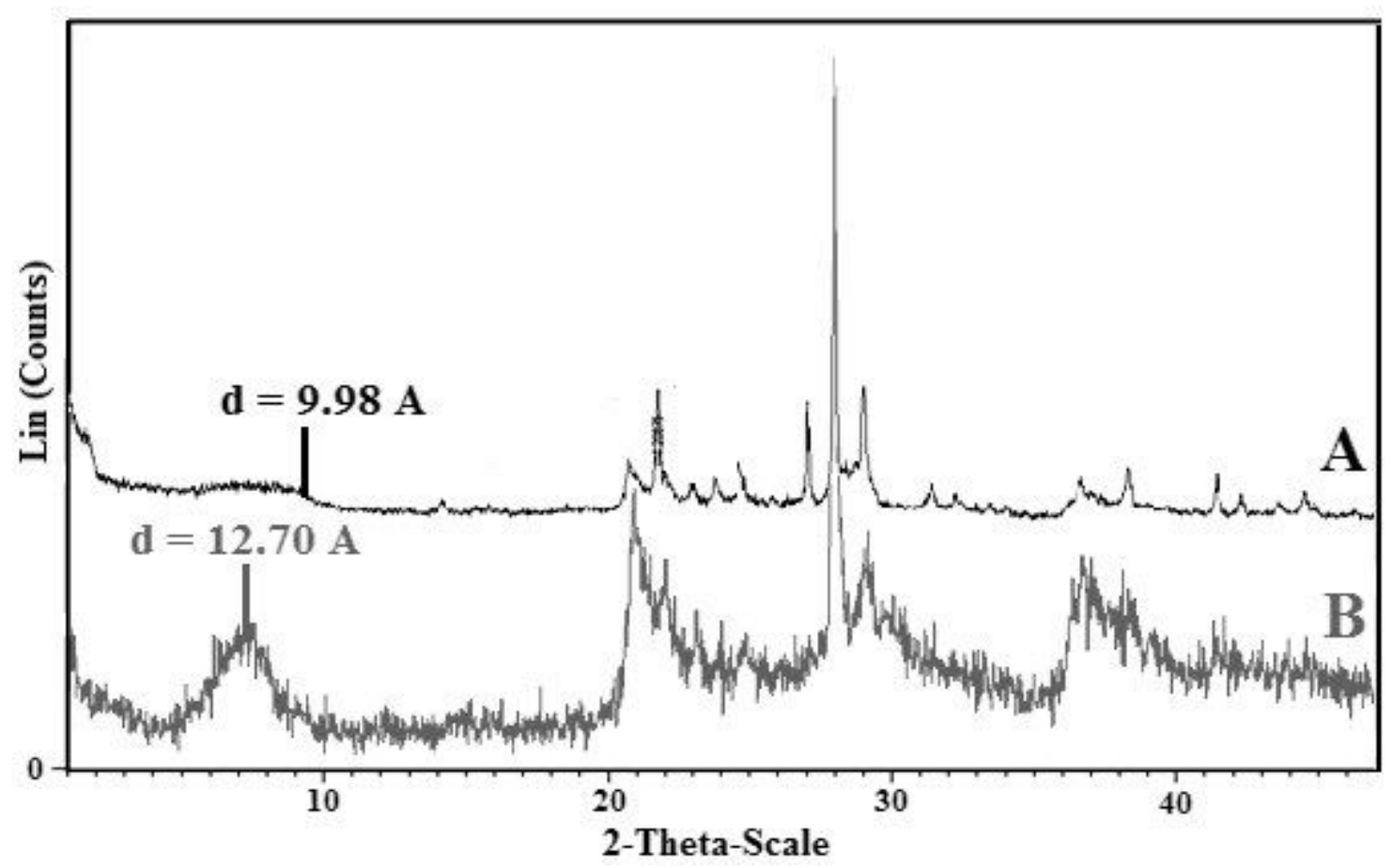

Figure 2

X-Ray Diffraction of: (A) Raw-Maghnite and (B) Maghnite-Na+

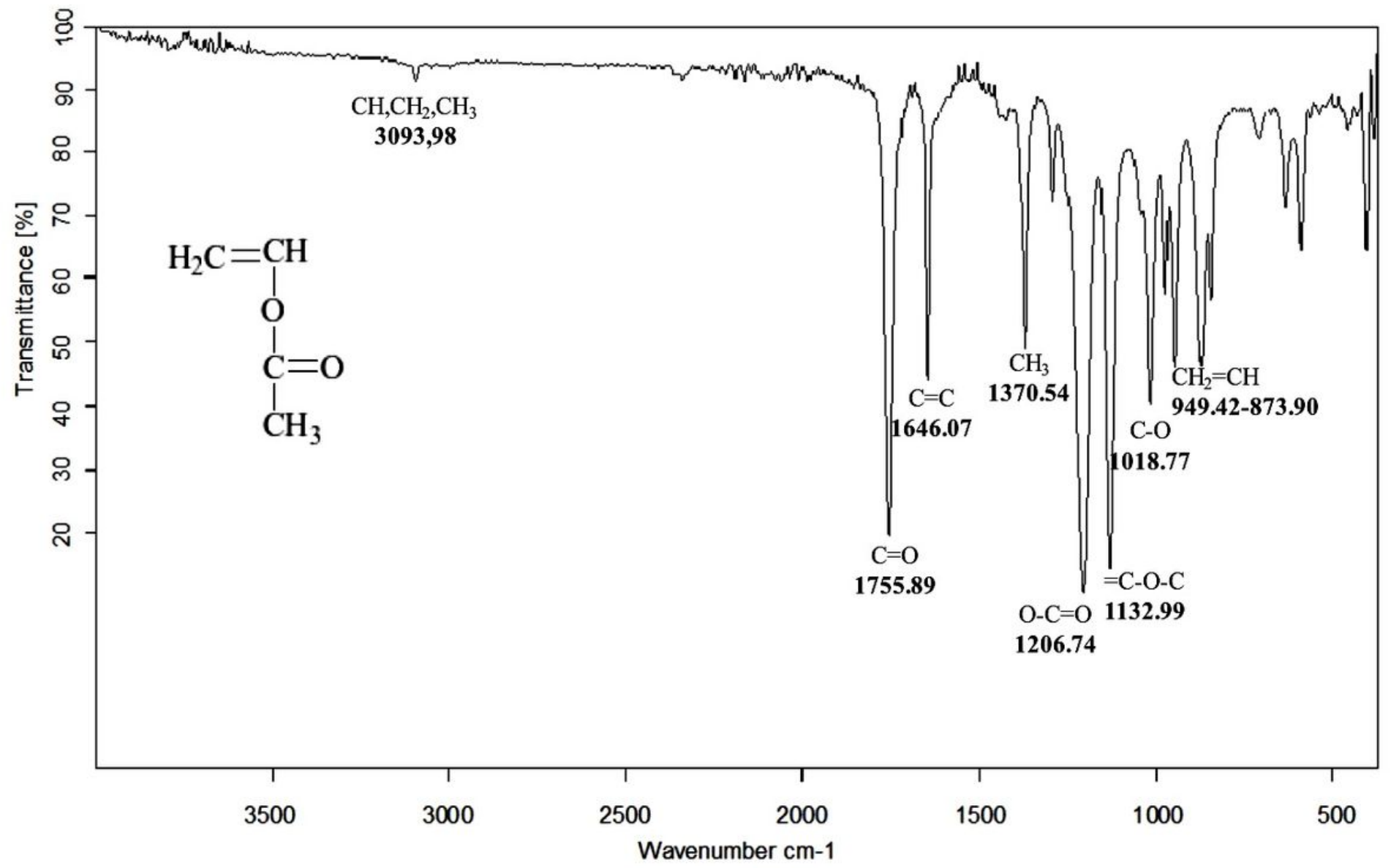

Figure 3 
FT-IR spectra of vinyl acetate (VAc) monomer.

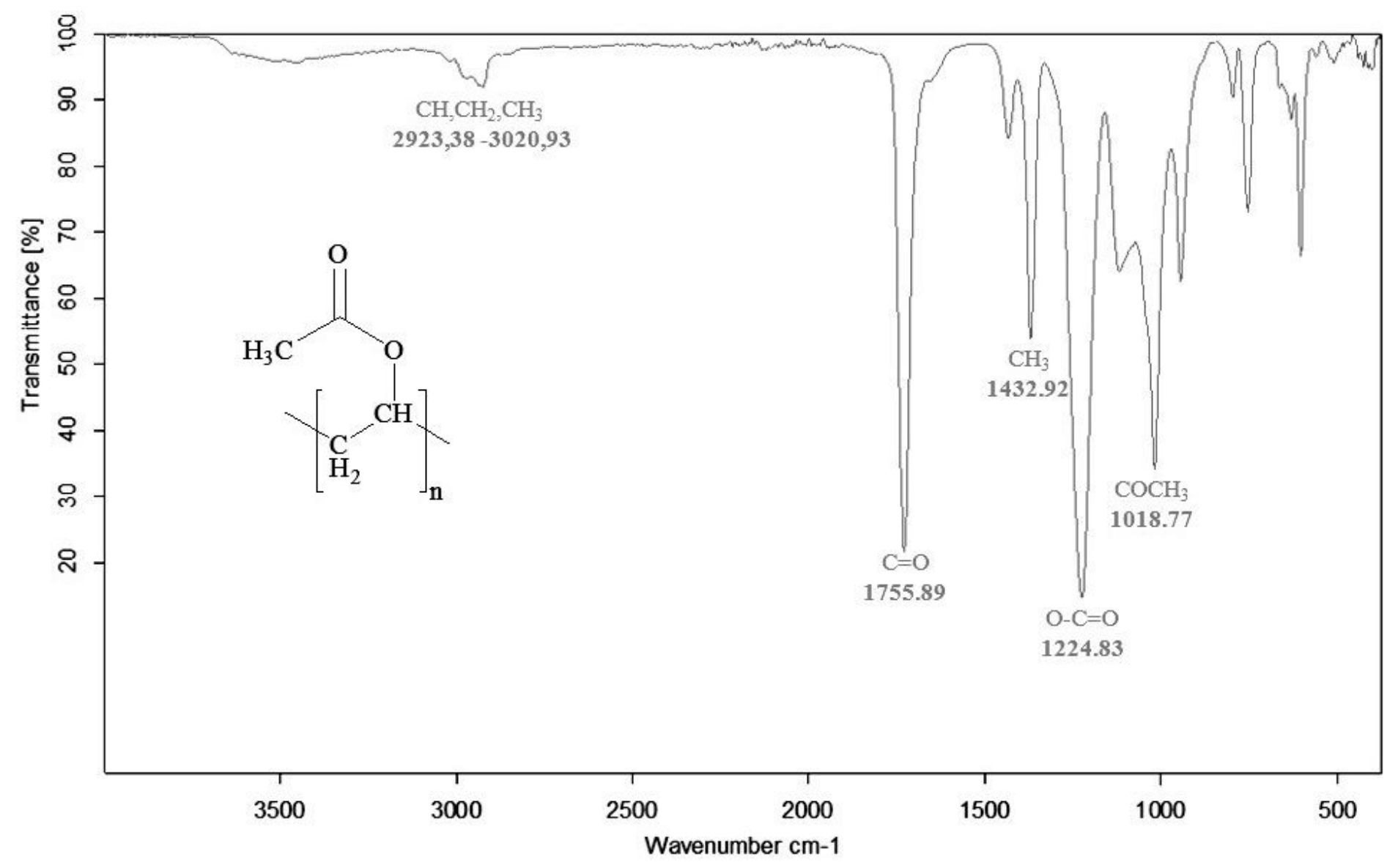

Figure 4

FT-IR spectra of Poly (vinyl acetate) synthesized. 


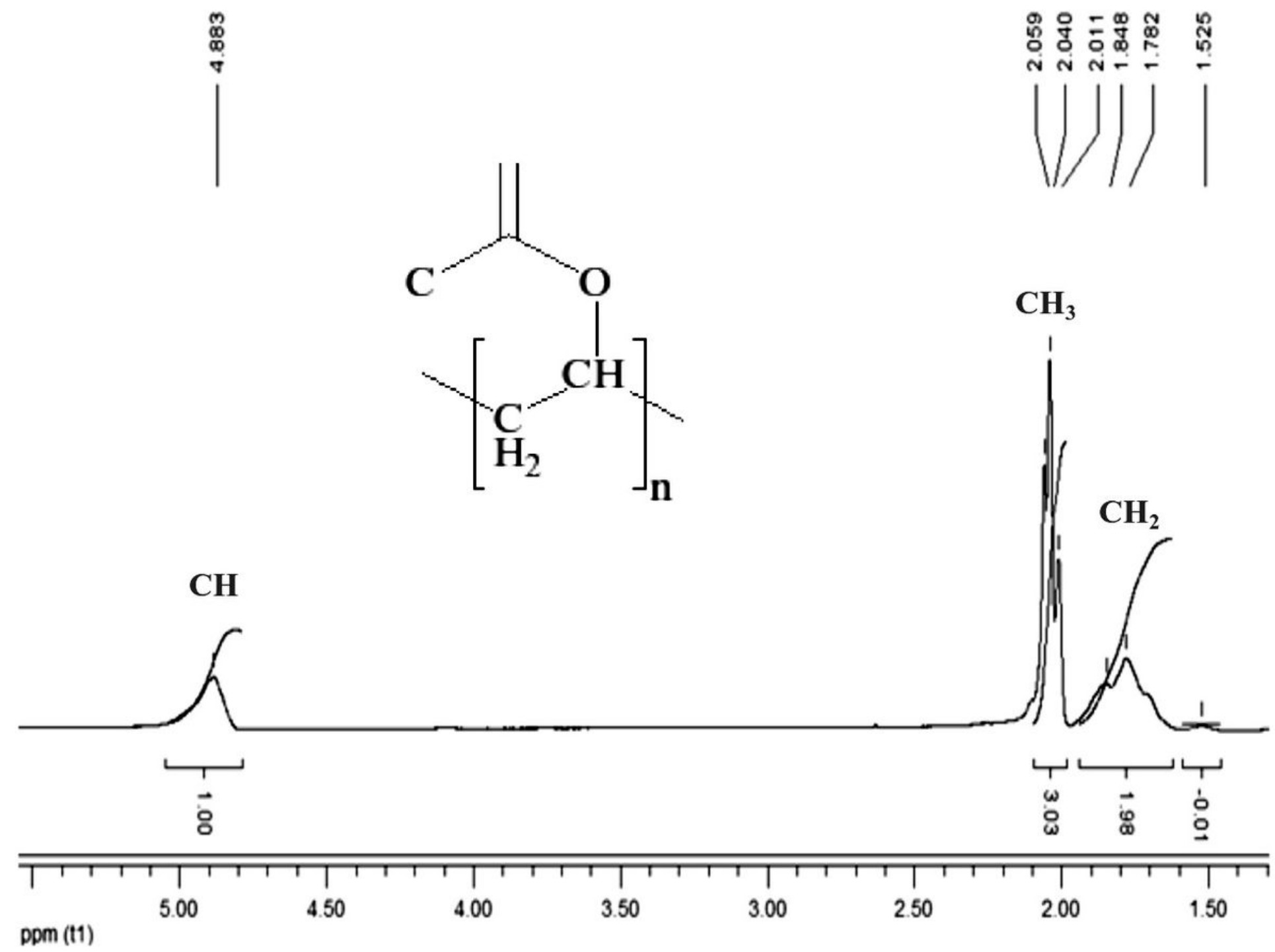

Figure 5

1H NMR spectrum of PVAc in (CDCl3). 


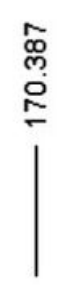

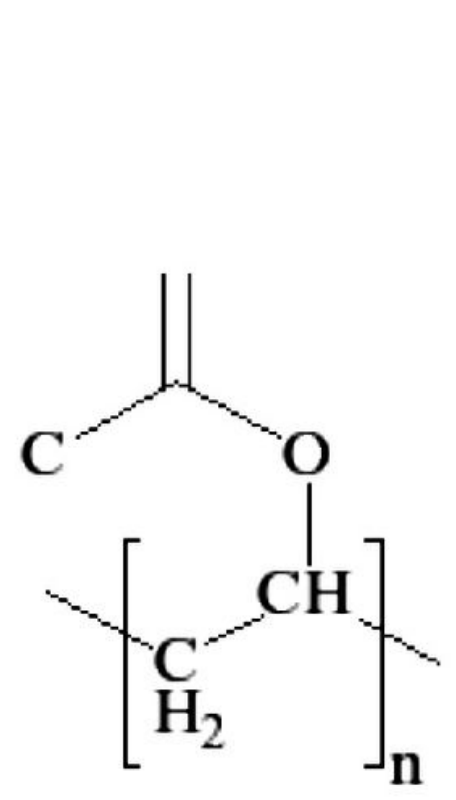

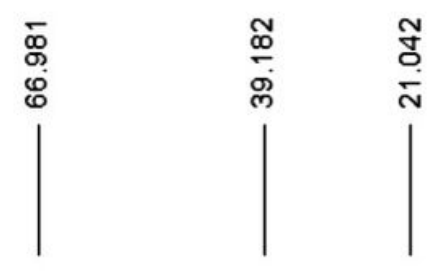

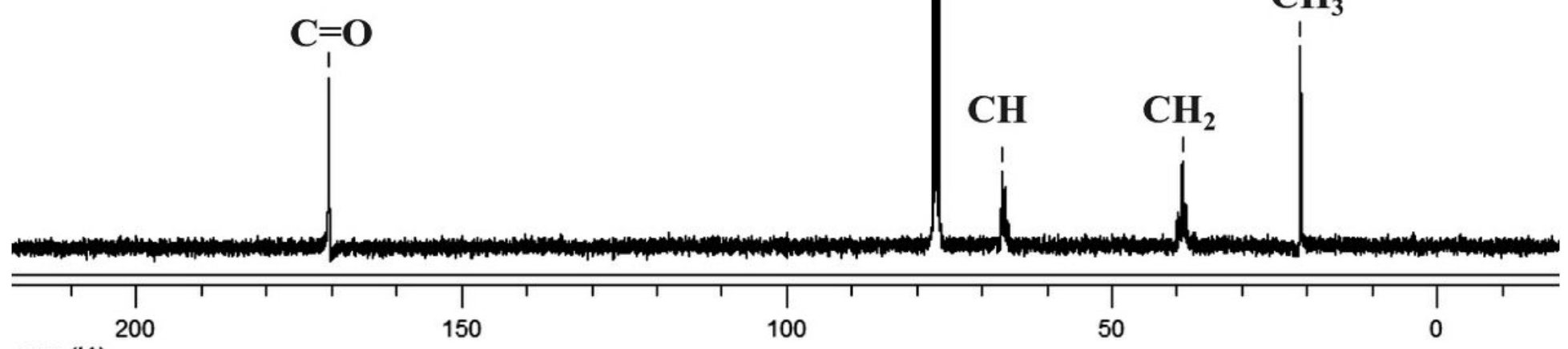

ppm (t1)

Figure 6

13C NMR spectrum of PVAc in (CDCl3) 


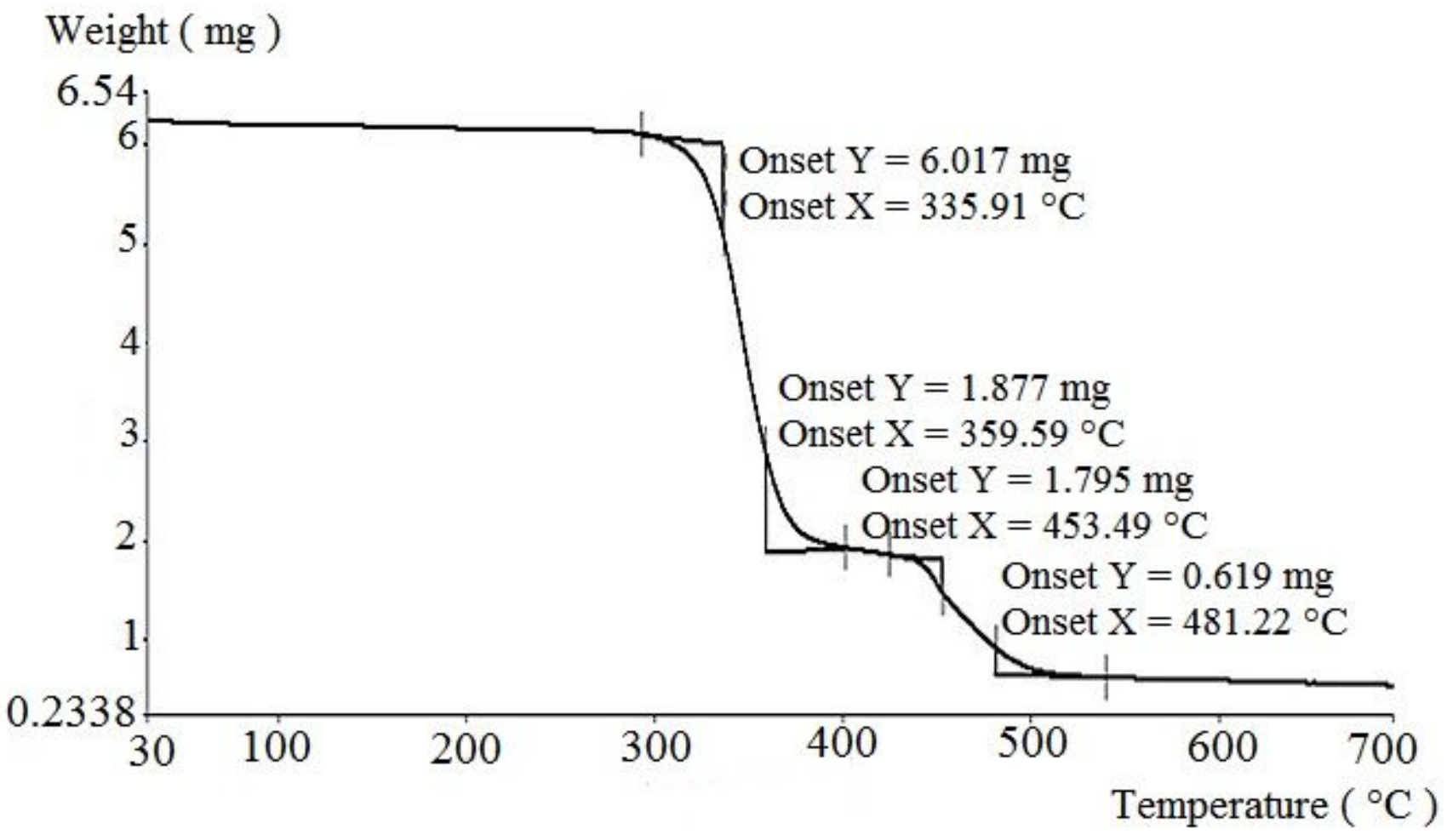

Figure 7

Thermogravimetric analysis TGA of PVAc catalyzed by Maghnite-Na+ (under N2). 


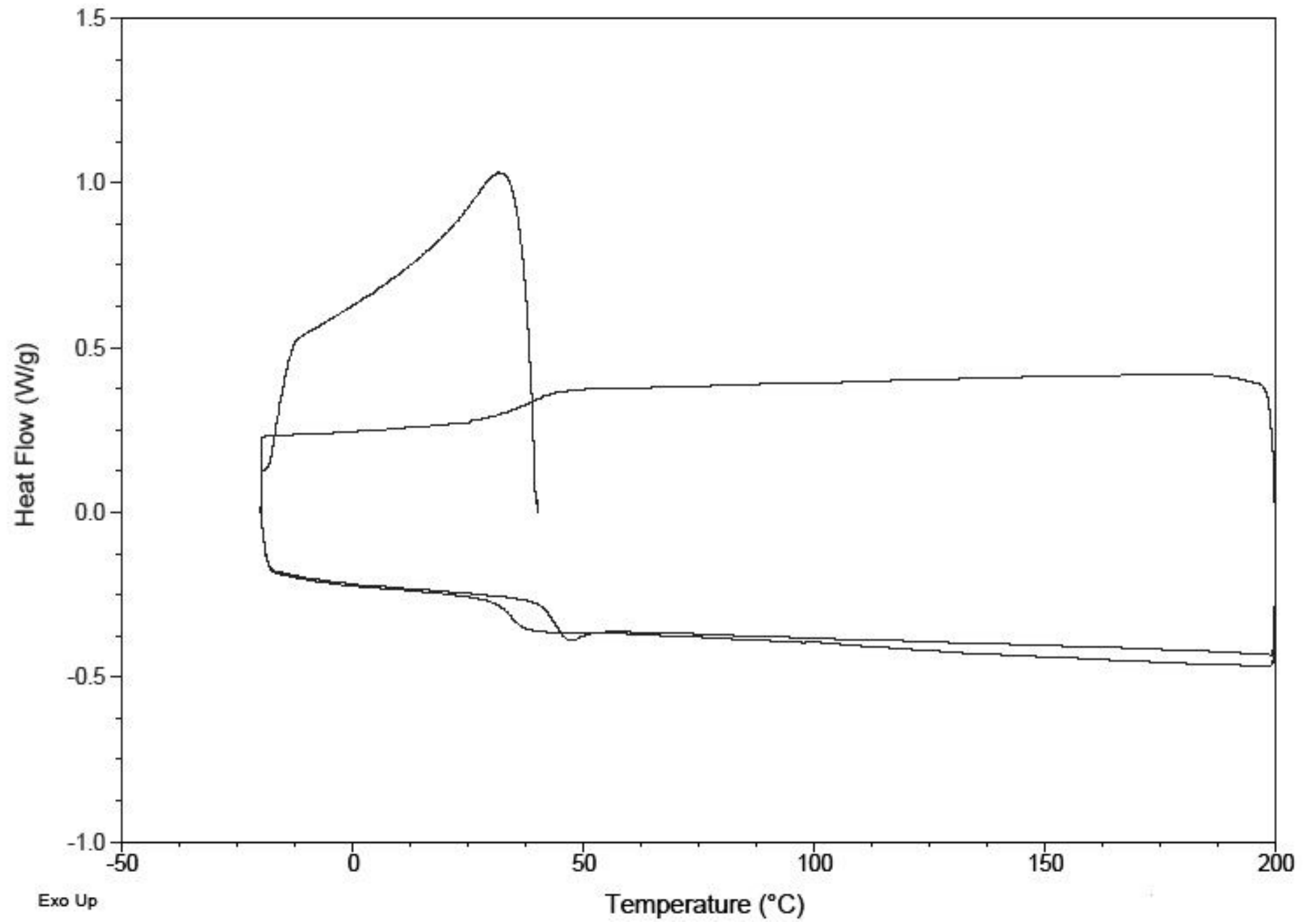

Figure 8

Differential scanning calorimetry (DSC) of PVAc catalyzed by Maghnite-Na+ (under N2) 

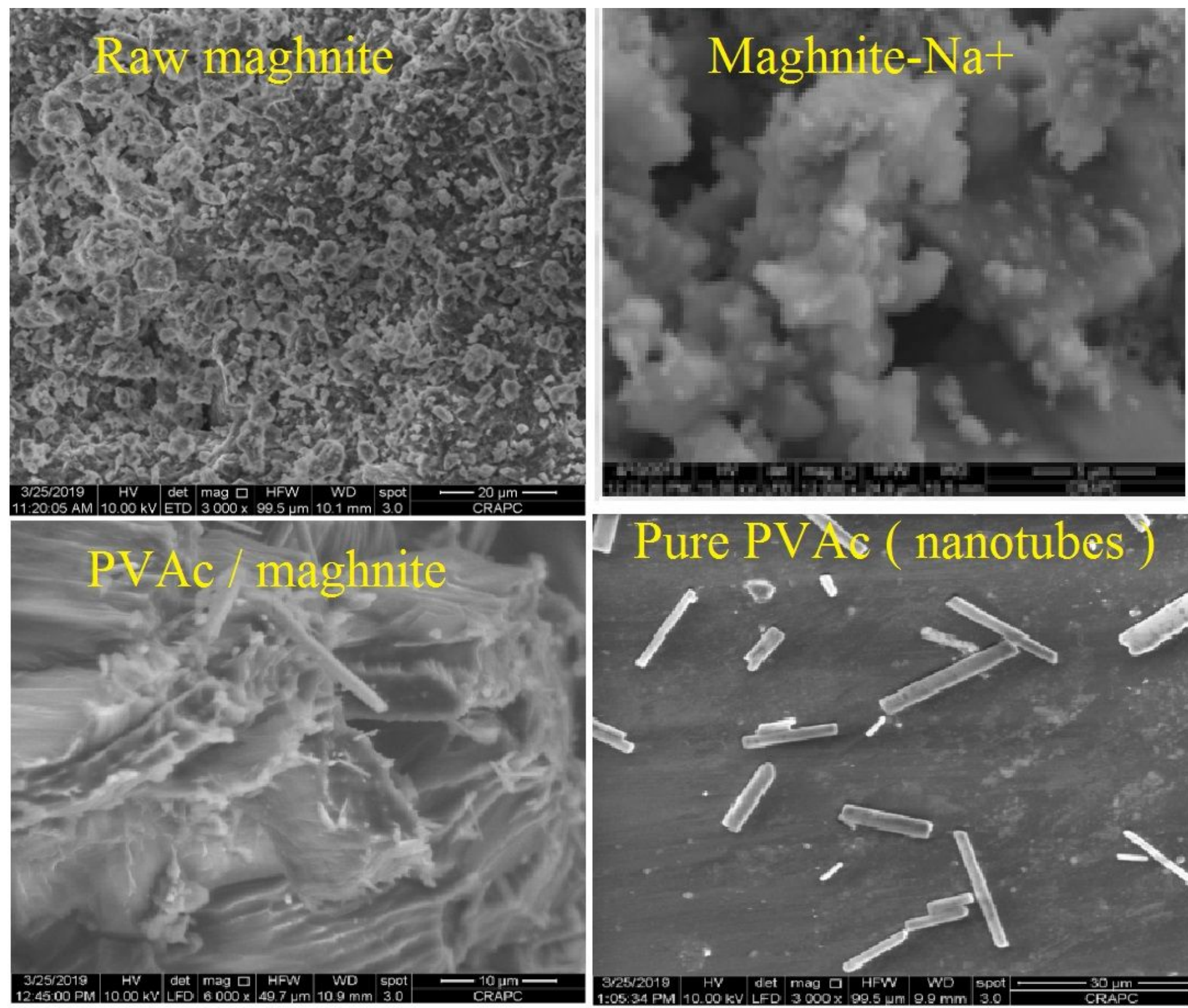

\section{Figure 9}

Scanning electron microscopic (SEM) images of : (A) raw maghnite (B) maghnite-Na+ (C) $\mathrm{PVAc} /$ maghnite-Na+ and (D) pure PVAc. 


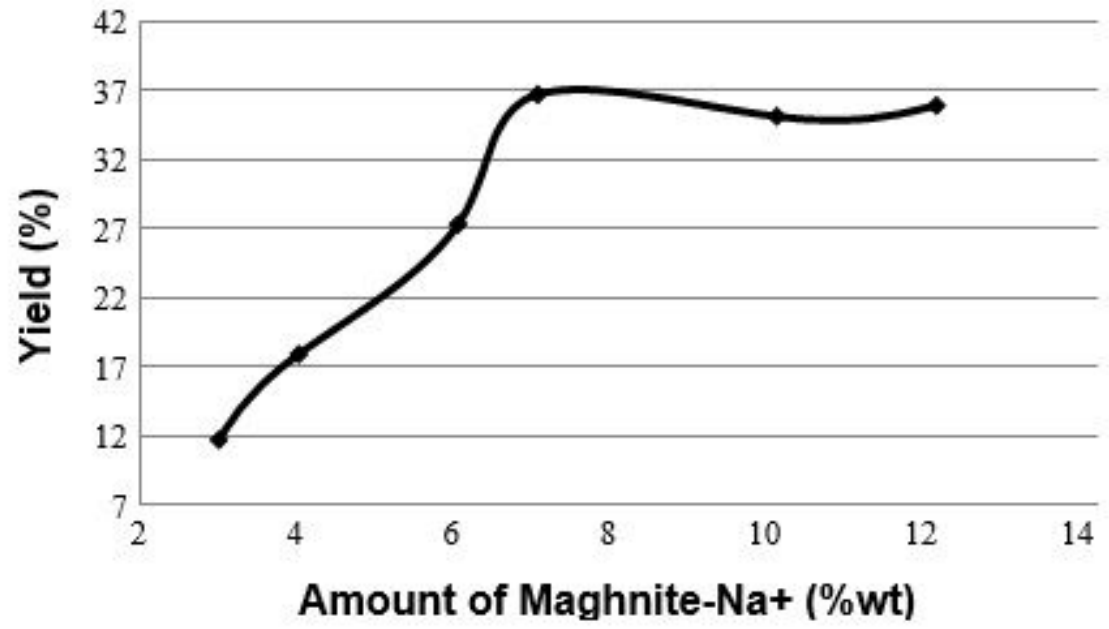

Figure 10

Effect of the amount of Maghnite-Na+ on the yield of PVAc : Reaction time (6h), Reaction temperature ( $\left.0^{\circ} \mathrm{C}\right)$, in bulk.

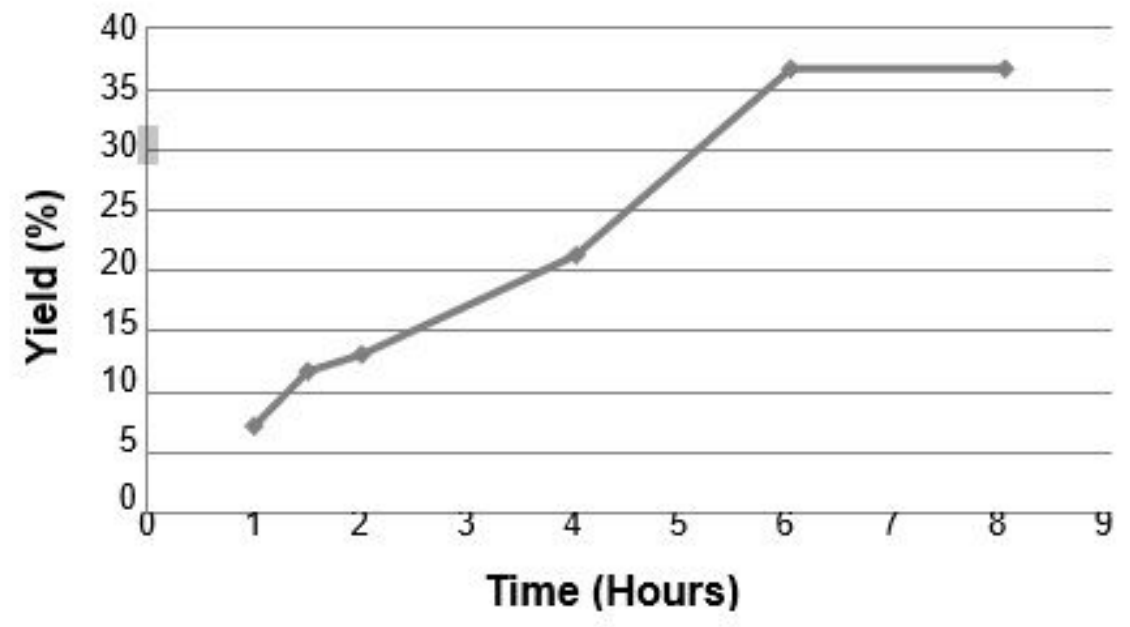

Figure 11

Effect of time on the yield of PVAc (Reaction temperature $=0{ }^{\circ} \mathrm{C}$, Mag-Na $+=7 \% \mathrm{wt}$, in bulk) 